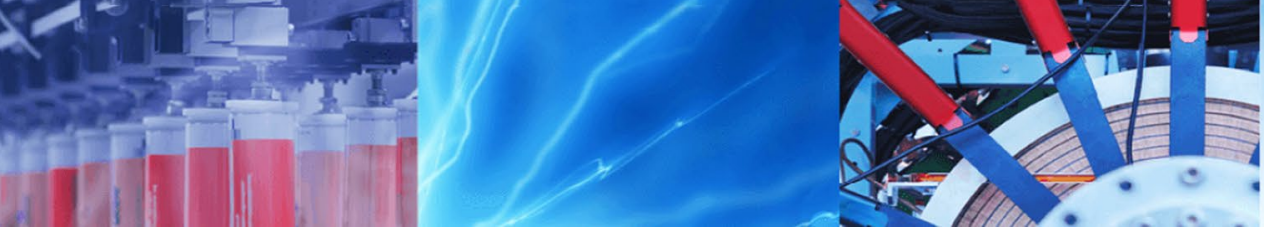

Research Article

\title{
Introducing an applied reactor for treatment of wastewater containing propylene glycol
}

\author{
Mahdi Ghaderi ${ }^{1} \cdot$ Amin Tamadoni $^{2} \cdot$ Asieh Mahdizadeh $^{2}$
}

Received: 15 September 2019 / Accepted: 5 November 2019 / Published online: 11 November 2019

(c) Springer Nature Switzerland AG 2019

\begin{abstract}
Propylene glycol (PG), classed as alcohol, has been used in many industrial additives. Leaching PG in aquatic environments would cause a significant decrease in dissolved oxygen, and this is the main reason for treatment of runoffs and wastewater contaminated with this pollutant. Previous researches on PG removal from wastewater indicate that biological methods are more economically suitable. Therefore, a new biological reactor was introduced and used for the treatment of wastewater containing PG. Two main approaches for increasing removal efficiency in presented research are utilizing two serial lab-scale Sequencing Batch Reactors and feed backward connection between these reactors. This novel reactor was named Feed Backward Serial Sequencing Batch Reactor. Moreover, response surface method was used for modeling of PG treatment and investigation of interactions and simultaneous effects of independent parameters. Retention time, influent COD, and flow recirculation percentage were considered as independent variables, where COD removal efficiency was the dependent variable. According to the results, the best COD removal efficiency was $47 \%$, and it was achieved in $3.52 \mathrm{~h}$ retention time, $1667.76 \mathrm{mg} / \mathrm{L}$ influent $\mathrm{COD}$, and $23.33 \%$ flow recirculation percentage. Based on the results of the presented research, PG treatment with the presented reactor is feasible.
\end{abstract}

Keywords Biological reactors · FBSSBR · Propylene glycol · Sequencing batch reactor

\section{Introduction}

In the contemporary world, different environmental problems have been caused as a result of constant development of additives and substances, most of which were supposed to enhance the quality of life $[2,4,54]$. Propylene glycol (PG) is one of these chemicals which is used in various industries including cosmetics, detergents, pesticides, foods, pharmaceutical, and most importantly aircraft deicing fluid, in tremendous amounts [53]. PG can affect organisms and the environment through penetrating groundwater [3] and leakage in surface water. PG significantly impacts marine life by reducing the dissolved oxygen [51]. Also it threatens human health with renal inadequacy and hepatic debilitation [55]. Based on these risks, PG treatment in wastewater seems to be necessary.

There are series of ways for industrial wastewater treatment such as physical, chemical and biological processes $[6,12,13,19,24,25,41,42]$. Studying about nano materials and using nano fluids is one of new research interests [33-40, 43-45]. Many ways are being used for PG contaminated wastewater treatment. Take, for instance, physical and chemical processes. The conclusion of these studies was that high cost is associated with chemical processes, and they produce secondary pollutants [30, 5]. Also, physical treatment methods showed low efficiency, and it only changed the ambiance of contamination [10, 14]. PG degradation with the Fenton process and $\mathrm{FeSO} 4, \mathrm{H}_{2} \mathrm{O}_{2}$ [51],

Mahdi Ghaderi, m.ghadery.ace@gmail.com | ${ }^{1}$ Mechanical Engineering Division, Torbat-e Jam High Educational Complex, Torbat-e Jam, Iran. ${ }^{2}$ Faculty of Civil Engineering, Babol Noshirvani University of Technology, Babol, Iran. 
and propylene glycol phenyl ether adsorption by activated carbon [52] are some physical and chemical procedures.

On the other hand, biological methods are immensely effective at a lower cost. Research on biological PG treatment has shown promising results. For instance, biological treatment of PG wastewater with methanogen bacteria in a semi-continuous reactor at a $35^{\circ} \mathrm{C}$ temperature reached $95 \%$ of COD removal (Sezgin and Tonuk [31]). In another research, activated sludge achieved $85 \%$ PG removal [48]. Ethylene glycol treatment from paint industries wastewater in a continuous biological system showed $97 \%$ removal efficiency [18].

However, bio-treatment is not flawless either. In the past century, activated sludge has been widely used in all kinds of wastewater treatment; this method requires a great deal of energy, biomass byproduct, operation cost, and sludge management cost. Many alternatives have been recommended because of technological achievements in the past decades; one such alternative is the sequence batch reactor (SBR) system $[20,46]$.

Several studies on complicated compound degradation have underscored the importance of ambiance conditions in SBR systems. These studies include research on hydraulic retention time (HRT) study on synthetic petroleum wastewater [32], and olive oil wastewater treatment with SBR [11].

Prediction is crucial in environmental engineering and was studied in previous researches [7, 8, 21, 26-29, 47]. In past studies, modeling, multivariate optimization, simultaneous effects of independent parameters, and synergistic and antagonistic effects of variables in biological treatment of contaminations were not considered. In this research, SBR was upgraded, and a new biological reactor called Feed Backward Serial Sequencing Batch Reactor (FBSSBR) was introduced. Application of FBSSBR in PG wastewater treatment was evaluated, for the first time. Modeling, multivariate optimization, simultaneous effects of independent parameters, and synergistic and antagonistic effects of variables in biological treatment of PG wastewater were done based on response surface methodology (RSM).

\section{Materials and methods}

\subsection{Reactor design}

According to Figs. 1 and 2, the FBSSBR reactor system had two similar reactors with $10 \mathrm{~cm}$ diameter, a height of $35 \mathrm{~cm}$, and volume of $2.75 \mathrm{~L}$ each. Furthermore, the indicator was placed $30 \mathrm{~cm}$ from the bottom. Accordingly, the effective height was $30 \mathrm{~cm}$, and effective

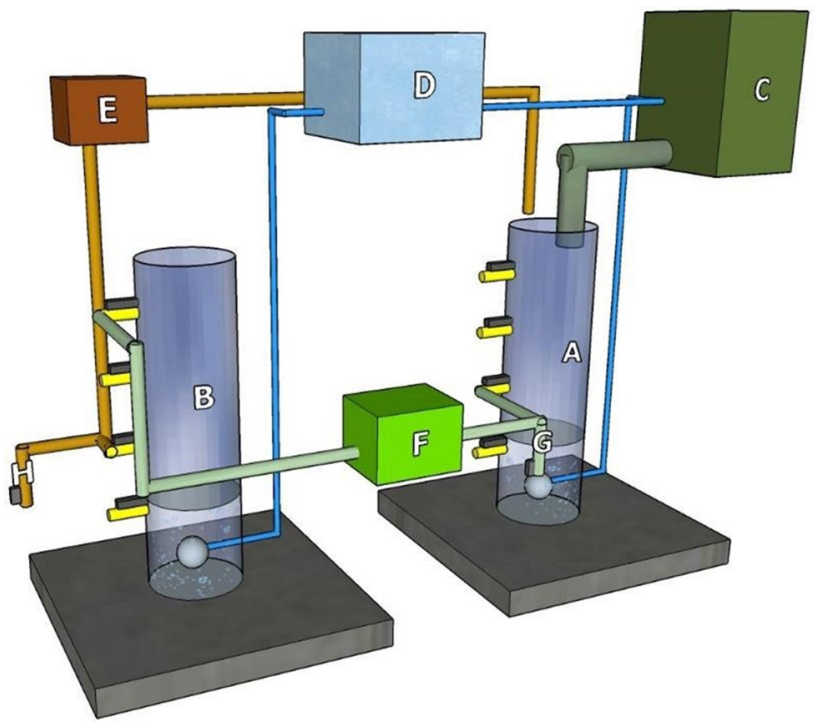

Fig. 1 3D scheme of feed backward serial sequencing batch reactor (A: reactor 1, B: reactor 2, C: feed container, D: aeration pump, E\&F: cycling pump, H\&G: sampling valve)

volume was $2.335 \mathrm{~L}$. The connection between two reactors for having an FBSSBR was with regular PVC tubes.

Each time the initial concentration of PG in wastewater was changed, the following steps were followed:

- At first, both reactors were full of wastewater, and then aeration units were turned on until the end of the retention time. Then aeration was stopped, and each reactor had $30 \mathrm{~min}$ time for settling time. Afterward, reactor two was emptied and used for concentration measurement, and reactor two was filled with the content of reactor 1 . Finally, reactor one was filled with raw wastewater from the feed container.

- Secondly, the two reactors were again aerated during their retention time, and in this stage, the wastewater was in circulation between two reactors through the connection pipes. So that, during the retention time, a certain percentage of each reactor volume was transferred to the other (the noted volume percentage in the adaptation phase was $40 \%$ and in the main experiment were as "flow recycling percent" column in Table 1). Then, as at the end of Step 1, reactor 2's content was discharged after the retention time and used for testing. Reactor 1's wastewater was pumped to reactor two and then, reactor one was filled with raw wastewater from the feed container.

- Finally, for each concentration of PG, step 2 was repeated until reaching steady-state conditions (less than 2\% difference in treatment efficiency). The removal efficiency in steady-state conditions was reported in this paper. 
Fig. 2 2D scheme of feed backward serial sequencing batch reactor

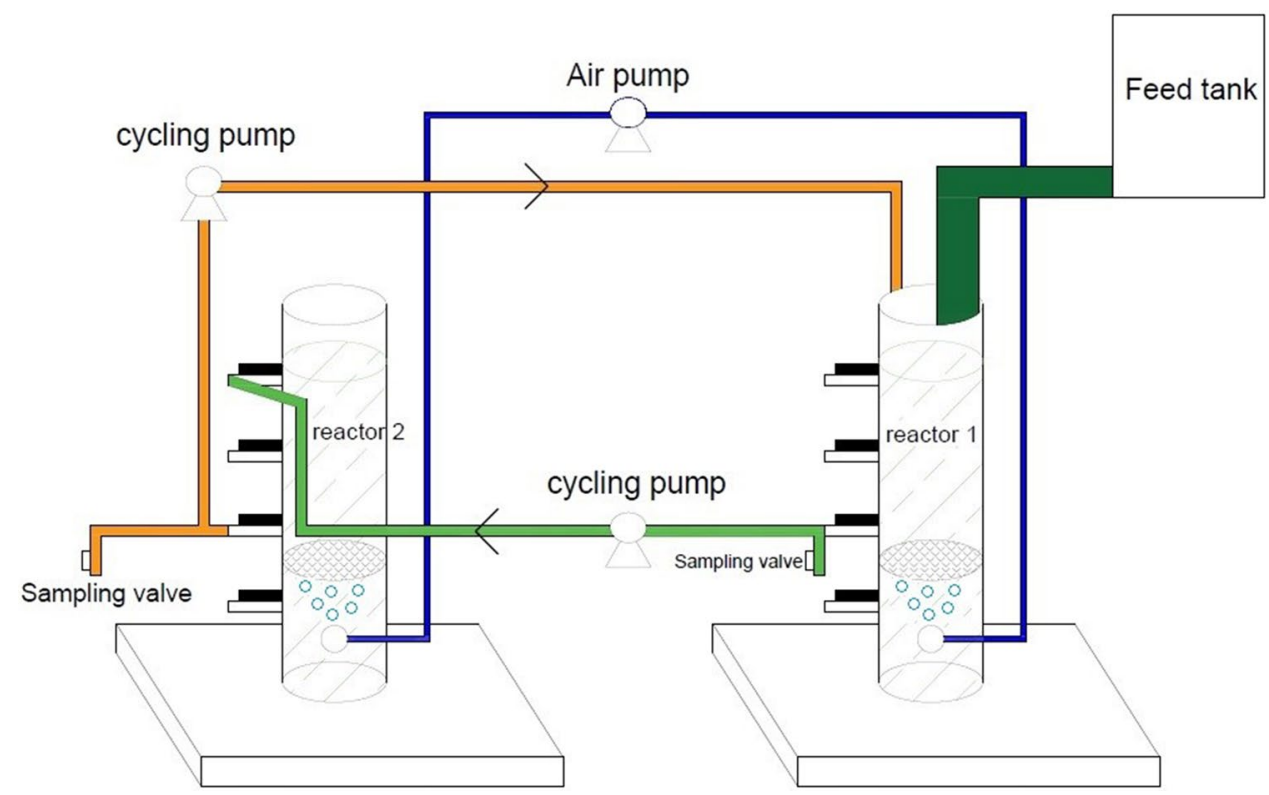

Table 1 RSM main experiments details

\begin{tabular}{llrl}
\hline Run & $\begin{array}{l}\text { Retention time } \\
(\mathrm{h})\end{array}$ & $\begin{array}{l}\text { Influent COD } \\
(\mathrm{mg} / \mathrm{L})\end{array}$ & $\begin{array}{l}\text { Flow recirculation } \\
\text { percentage }(\%)\end{array}$ \\
\hline 1 & 5.00 & 1500.00 & 27.50 \\
2 & 3.00 & 900.00 & 20.00 \\
3 & 5.00 & 1500.00 & 27.50 \\
4 & 5.00 & 1500.00 & 40.11 \\
5 & 3.50 & 2100.00 & 20.00 \\
6 & 5.00 & 1500.00 & 27.50 \\
7 & 7.52 & 1500.00 & 27.50 \\
8 & 3.50 & 900.00 & 35.00 \\
9 & 2.48 & 1500.00 & 27.50 \\
10 & 6.50 & 2100.00 & 35.00 \\
11 & 5.00 & 1500.00 & 14.89 \\
12 & 3.50 & 2100.00 & 35.00 \\
13 & 5.00 & 1500.00 & 27.50 \\
14 & 6.50 & 900.00 & 35.00 \\
15 & 6.50 & 900.00 & 20.00 \\
16 & 5.00 & 1500.00 & 27.50 \\
17 & 6.50 & 2100.00 & 20.00 \\
18 & 5.00 & 1500.00 & 27.50 \\
19 & 5.00 & 490.92 & 27.50 \\
20 & 5.00 & 2509.08 & 27.50 \\
\hline & & &
\end{tabular}

\subsection{Dependent and independent parameters and RSM}

In this research, a completely new reactor (FBSSBR) was introduced for the biological treatment of propylene glycol. The primary purposes of this research were statistical analysis, modeling, and determination of optimum conditions. For these objectives, the experiments were designed with the response surface methodology.

Response surface methodology has been used in environmental studies, previously $[1,17,22,23,49,50]$. The foundation of RSM is mathematical and statistical techniques. In RSM, linear or square polynomial functions are used for modeling, optimization, and system study [9].

RSM modeling requires effective factors selection. The next step in modeling is determining each factor's maximum and minimum for experimental matrix design. This process shows the number of main experiment tests. The main goal of the experimental design is to obtain statistically reliable results. The code levels $(+1)$ and $(-1)$ indicate the maximum and minimum limits of each parameter that these two levels should determine based on the main idea of the study. Finally, there is a third level or central (0) between the maximum and minimum.

Design-Expert 7.0.0 software was used for experimental design and analysis of the results. Based on the conditions mentioned in Table 2, three independent variables (retention time, influent $C O D$, and flow recirculation percentage) and a dependent variable of COD removal were selected, and RSM model suggested twenty experiments for the main experiments.

\subsection{Microorganisms preparing and adaptation; nutrient compound details}

Microorganisms were prepared from returned sludge to activated sludge tank in a municipal wastewater treatment plant. Around $40 \%$ of the reactors' volume was filled with sludge (microorganisms), and the rest of the effective 
Table 2 RSM design, experiments condition summary

\begin{tabular}{lllcrrrr}
\hline Factor & Units & Type & Low actual & High actual & Low coded & High coded & Mean \\
\hline Retention time & $\mathrm{h}$ & Numeric & 3.50 & 6.50 & -1.000 & 1.000 & 5.00 \\
Influent COD & $\mathrm{mg} / \mathrm{L}$ & Numeric & 900.00 & 2100.00 & -1.000 & 1.000 & 1500.00 \\
$\begin{array}{l}\text { Flow recircula- } \\
\text { tion percent- }\end{array}$ & & Numeric & 20.00 & 35.00 & -1.000 & 1.000 & 27.50 \\
$\quad$ & & & & & & \\
age & & & & & & \\
\hline
\end{tabular}

Table 3 RSM main experiments details

\begin{tabular}{ll}
\hline Parameter & Measure \\
\hline $\mathrm{PH}$ & 7.2 \\
Temperature $\left({ }^{\circ} \mathrm{C}\right)$ & 20 \\
Dissolved oxygen $(\mathrm{mg} / \mathrm{L})$ & 1.8 \\
Total suspended solid $(\mathrm{mg} / \mathrm{L})$ & 3500 \\
\hline
\end{tabular}

volume was filled with wastewater. Table 3 indicates some necessary details of used sludge.

The aeration pump adjusted to mix the reactor content slowly by aeration and keep the dissolved oxygen near $1.5-2.5 \mathrm{mg} / \mathrm{L}$. In specific periods, $\mathrm{pH}$ was kept fixed in the range of 6.8-7.2. The experiments were conducted at an ambient temperature between 21 and $25^{\circ} \mathrm{C}$. Inlet COD concentration was 200 ( $\mathrm{mg} / \mathrm{L})$ during the adaptation period. At the beginning of each cycle, reactors were fed with 100:5:1, C:N:P ratio wastewater. In the adaptation phase, carbon was from glucose and propylene glycol, and in the main experiments, it was from propylene glycol.

The adaptation nutrients order form glucose and PG feed were in accordance with Fig. 3 . In the feeding period, retention time was $7.5 \mathrm{~h}$ and $40 \%$ of reactors volume could circulate between two reactors. For each input, this would be repeated until FBSSBR reached the steady-state condition. In all of the situations in Fig. 3, removal efficiency was $100 \%$. After microorganism adaptation, in the main experiments (Table 1), PG was used as carbon source. Urea was the primary nitrogen source, and $\mathrm{KH} 2 \mathrm{PO} 4$ was the phosphor source. C:N:P ratio was fixed in the range of 100:5:1 during all experiments. Table 4 represents other details about micronutrients, which were used to increase the efficiency and activity of microorganisms.

\subsection{Experiments instructions}

In this research, all experiments were conducted in line with Standard Methods for the Examination of Water and Wastewater [16].

\section{Results and discussions}

As mentioned, three main factors (retention time, influent COD, and flow recirculation percentage) were used as independent variables. For each run, removal efficiencies were determined, and they are presented in Table 5. According to Table 5, maximum removal efficiency was
Fig. 3 Order of nutrient compound input from glucose and PG for adaptation feeding

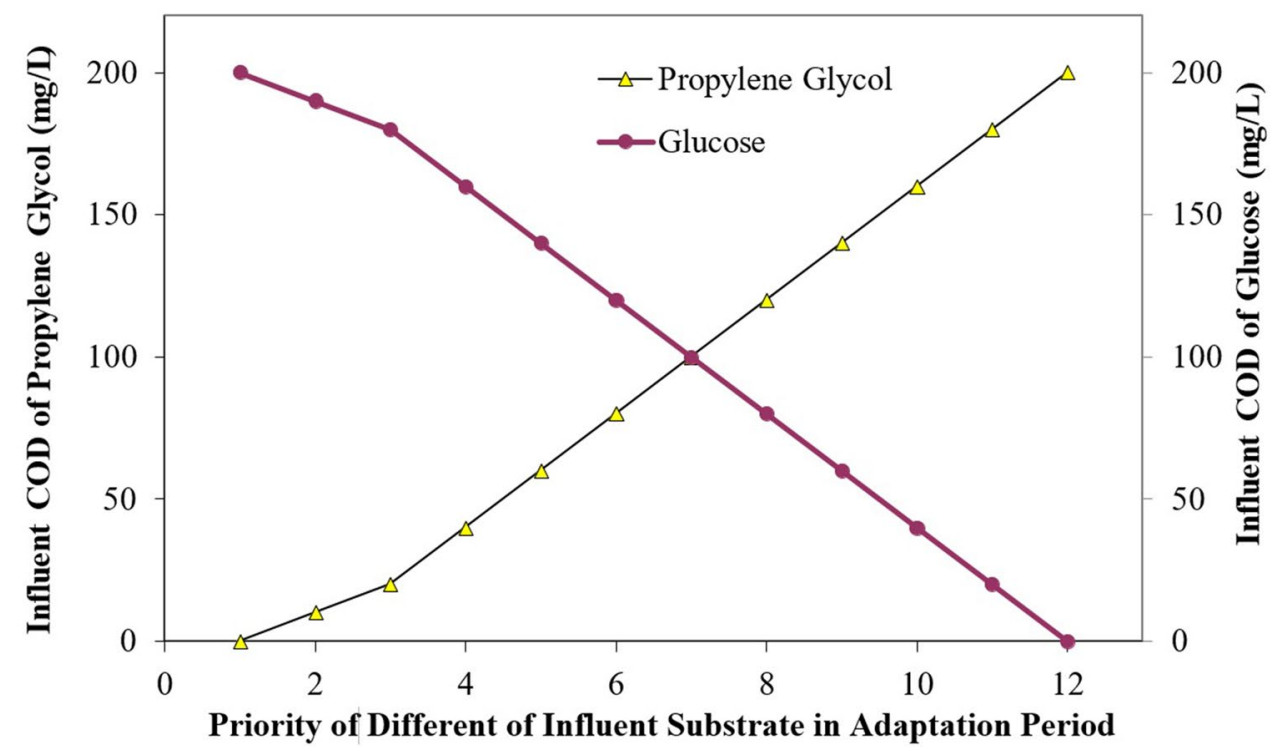


Table 4 details of used micronutrients

\begin{tabular}{llll}
\hline Ingredients & Compound name & Chemical formula & $\begin{array}{l}\text { Adaptation } \\
\text { concentrate } \\
\text { (mg/L) }\end{array}$ \\
\hline Carbon source & Glucose & $\mathrm{C}_{6} \mathrm{H}_{12} \mathrm{O}_{6} \cdot 6 \mathrm{H}_{2} \mathrm{O}$ & $0-200$ \\
& Propylene glycol & $\mathrm{C}_{3} \mathrm{H}_{4} \mathrm{O}_{2}$ & $0-200$ \\
Nutrients & Urea & $\mathrm{H}_{2} \mathrm{NCONH}_{2}$ & 10 \\
& Potassium hydrogen phosphate & $\mathrm{K}_{2} \mathrm{HPO}_{4}$ & 1 \\
& Potassium dihydrogen phosphate & $\mathrm{KH}_{2} \mathrm{PO}_{4}$ & 1 \\
Small nutrients & Magnesium sulphate & $\mathrm{MgSO}_{4} \cdot 7 \mathrm{H}_{2} \mathrm{O}$ & 5 \\
& Calcium chloride & $\mathrm{CaCl}_{2}$ & 3.75 \\
& Iron(III)chloride & $\mathrm{FeCl}_{3} \cdot 6 \mathrm{H}_{2} \mathrm{O}$ & 1 \\
& Sodium molybdate & $\mathrm{Na}_{2} \mathrm{MoO}_{4} \cdot 2 \mathrm{H}_{2} \mathrm{O}$ & 1.26 \\
\hline
\end{tabular}

Table 5 Removal efficiency of RSM main experiments

\begin{tabular}{lllll}
\hline Run & $\begin{array}{l}\text { Retention } \\
\text { time }(\mathrm{h})\end{array}$ & $\begin{array}{l}\text { Influ- } \\
\text { ent COD } \\
(\mathrm{mg} / \mathrm{L})\end{array}$ & $\begin{array}{l}\text { Flow recircula- } \\
\text { tion percentage }\end{array}$ & $\begin{array}{l}\text { Removal effi- } \\
\text { ciency percent- } \\
\text { age }\end{array}$ \\
\hline 1 & 5 & 1500 & 27.50 & 67 \\
2 & 3 & 900 & 20 & 70 \\
3 & 5 & 1500 & 27.50 & 67 \\
4 & 5 & 1500 & 40.11 & 78 \\
5 & 3.50 & 2100 & 20 & 30 \\
6 & 5 & 1500 & 27.50 & 67 \\
7 & 7.52 & 1500 & 27.50 & 83 \\
8 & 3.50 & 900 & 35 & 85 \\
9 & 2.48 & 1500 & 27.50 & 36 \\
10 & 6.50 & 2100 & 35 & 74 \\
11 & 5 & 1500 & 14.89 & 64 \\
12 & 3.50 & 2100 & 35 & 38 \\
13 & 5 & 1500 & 27.50 & 67 \\
14 & 6.50 & 900 & 35 & 96 \\
15 & 6.50 & 900 & 20 & 93 \\
16 & 5.00 & 1500 & 27.50 & 67 \\
17 & 6.50 & 2100 & 20 & 56 \\
18 & 5 & 1500 & 27.50 & 67 \\
19 & 5 & 490.92 & 27.50 & 98 \\
20 & 5 & 2509.08 & 27.50 & 45 \\
\hline & & & &
\end{tabular}

$98 \%$ in $5 \mathrm{~h}$ retention time, $490.92 \mathrm{mg} / \mathrm{L}$ of initial COD concentration, and $27.5 \%$ recycling flow rate.

\subsection{Individual effect of each parameter}

One dimensional diagram represents each factor's effect on the removal efficiency percentage separately. In each discussion, two out of three independent variables were considered as a fixed value, and the removal efficiency diagram was illustrated based on effect of one variable.

\subsubsection{The effect of retention time}

Figure 4 shows the removal efficiency in different retention times. According to the results, change of retention time between 3.5 and $6.5 \mathrm{~h}$ would cause removal efficiency to increase from $51 \%$ to nearly $77 \%$. Hence, it can be concluded that in the FBSSBR system, removal efficiency and retention time are directly related. Previous researchers could confirm this augment; for example, in a fixed bed activated hybrid sludge reactor, there was a similar trend of increase in removal efficiency after increasing retention time [15]. This is in that microorganisms have more consumption and more contact with the contamination within the longer retention time.

\subsubsection{The effect of influent COD concentration}

Figure 5 shows the removal efficiency percentage in different influent COD concentrations. The inverse relationship between inlet COD and removal efficiency is apparent because toxicity increases when COD increases. In other words, in high PG concentrations, microorganisms will lose their metabolic. This research attempts to improve the ability of microorganisms in the FBSSBR system with the adaptation phase.

In Fig. 5, influent COD concentration changes in the range of $900-2100 \mathrm{mg} / \mathrm{L}$. Based on the outcomes, the removal efficiency was $87 \%$ for $900 \mathrm{mg} / \mathrm{L}$ initial COD concentration, and close to $50 \%$ for $2100 \mathrm{mg} / \mathrm{L}$ initial COD.

Synthetic PG wastewater treatment in an activated sludge reactor showed the same trend [48]. A Fixed Bed Activated Sludge Hybrid Reactor also showed the reduction of removal efficiency by increasing in influent $C O D$ [15]. Wastewater containing PG (Paint industries' wastewater) treatment with submerged attached growth reactor (SAGR) in both batch and continuous conditions validated this research result. 
Fig. 4 The effect of retention time on COD removal efficiency (Influent $\mathrm{COD}=1500 \mathrm{mg} / \mathrm{L}$, flow recirculation percentage $=27.5 \%$ )

Fig. 5 The effect of influent COD concentration on COD removal efficiency (Retention time $=5 \mathrm{~h}$, flow recirculation percentage $=27.5 \%$ )
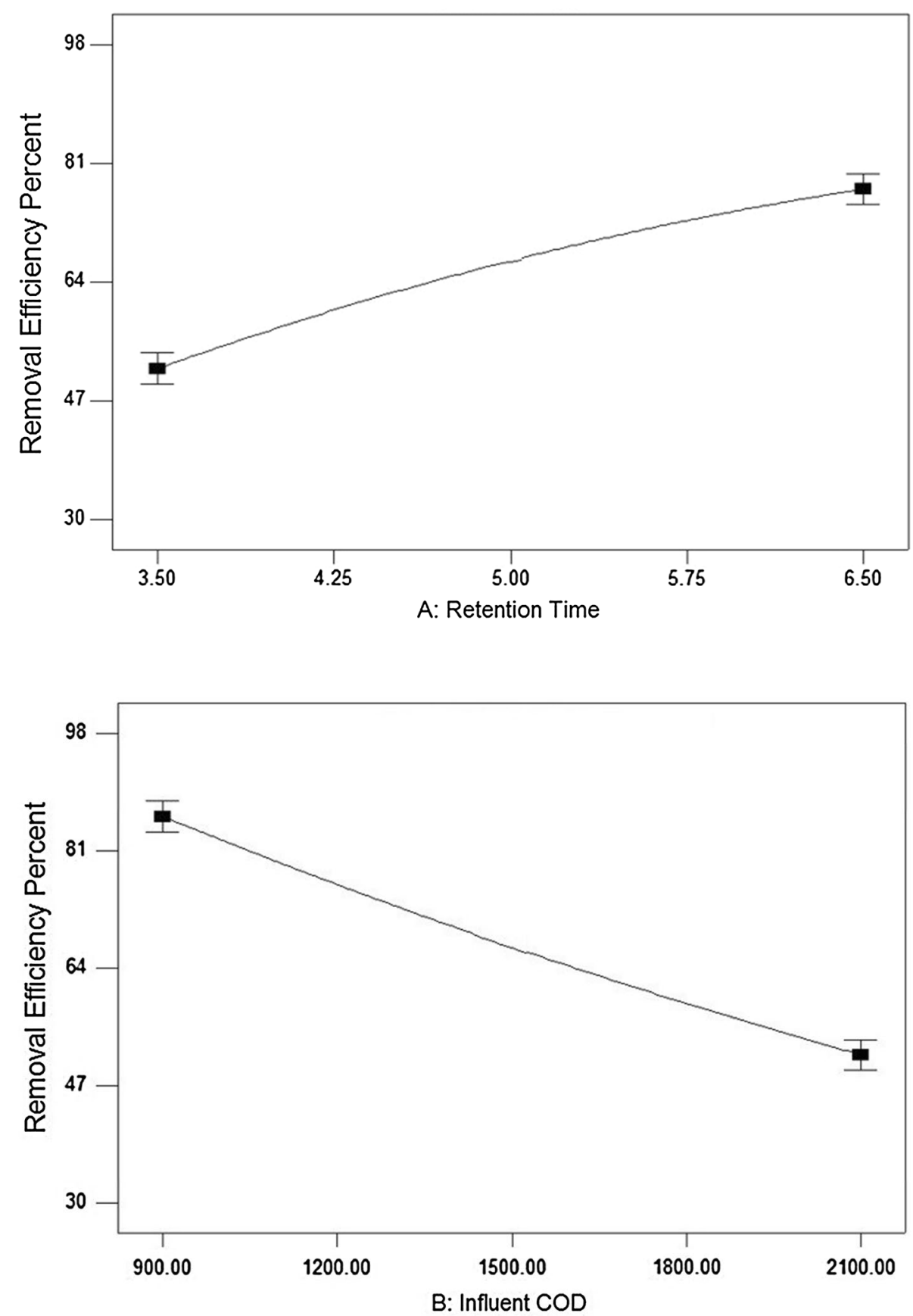

\subsubsection{The effect of flow recirculation percentage}

As seen in Fig. 6, removal efficiency and flow recirculation percentage have a direct relation. By increasing the flow recirculation percentage from 20 to $35 \%$, removal efficiency also increased from $64 \%$ (540 mg/L output COD) to $73 \%$ ( $405 \mathrm{mg} / \mathrm{L}$ output COD). Flow recirculation percentage was investigated for the first time in this research by introducing FBSSBR reactor, which has a positive effect on removal efficiency.

SN Applied Sciences

\subsection{Simultaneous effect of parameters}

\subsubsection{The effect of retention time and influent COD concentration}

The simultaneous effect of retention time and influent COD concentration on COD removal efficiency was shown in Fig. 7. With influent COD concentration changing between 900 and $2100 \mathrm{mg} / \mathrm{L}$ and retention time between 3.5 and $6.5 \mathrm{~h}$, removal efficiency was improved from $32 \%$ (for $2100 \mathrm{mg} / \mathrm{L} \mathrm{COD}$ and $3.5 \mathrm{~h}$ retention time) to $89.75 \%$ 
Fig. 6 The effect of flow recirculation percentage on COD removal efficiency (Retention time $=5 \mathrm{~h}$, Influent $\mathrm{COD}=1500 \mathrm{mg} / \mathrm{L}$ )

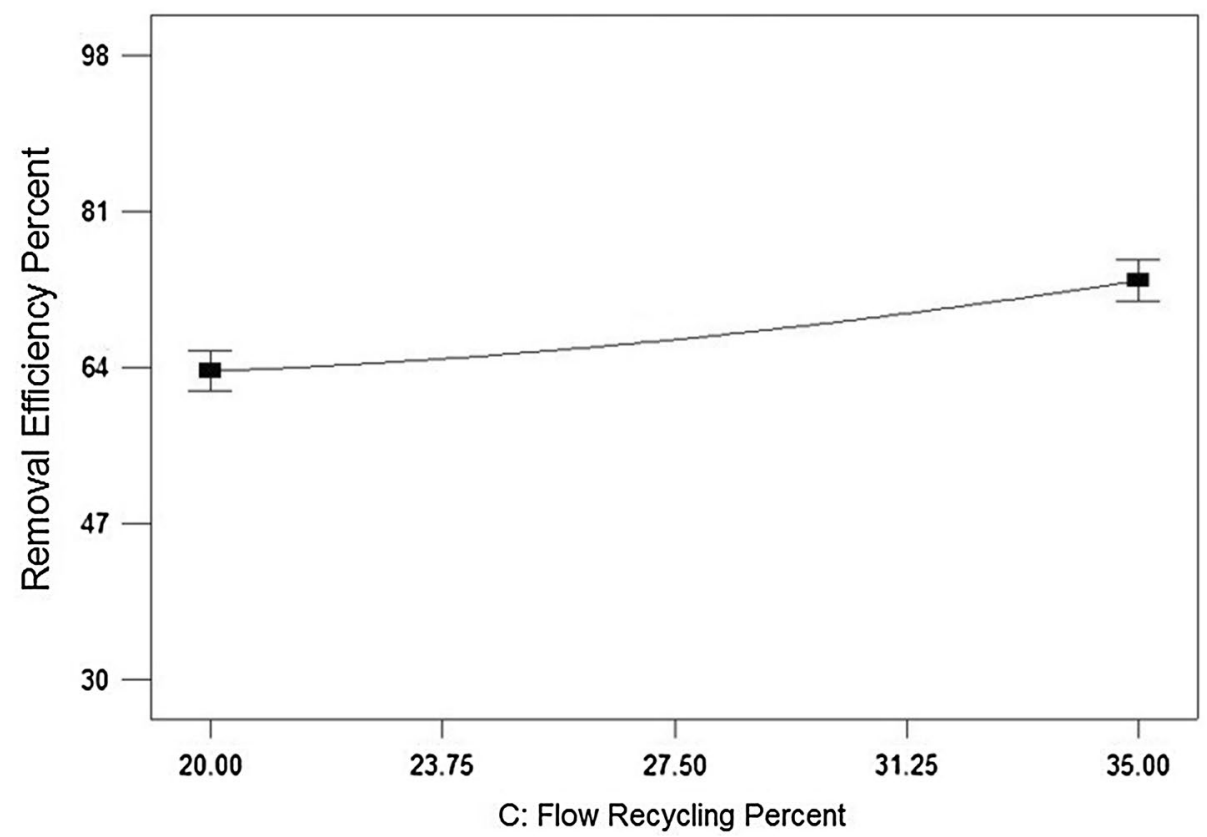

Removal Efficiency Percent

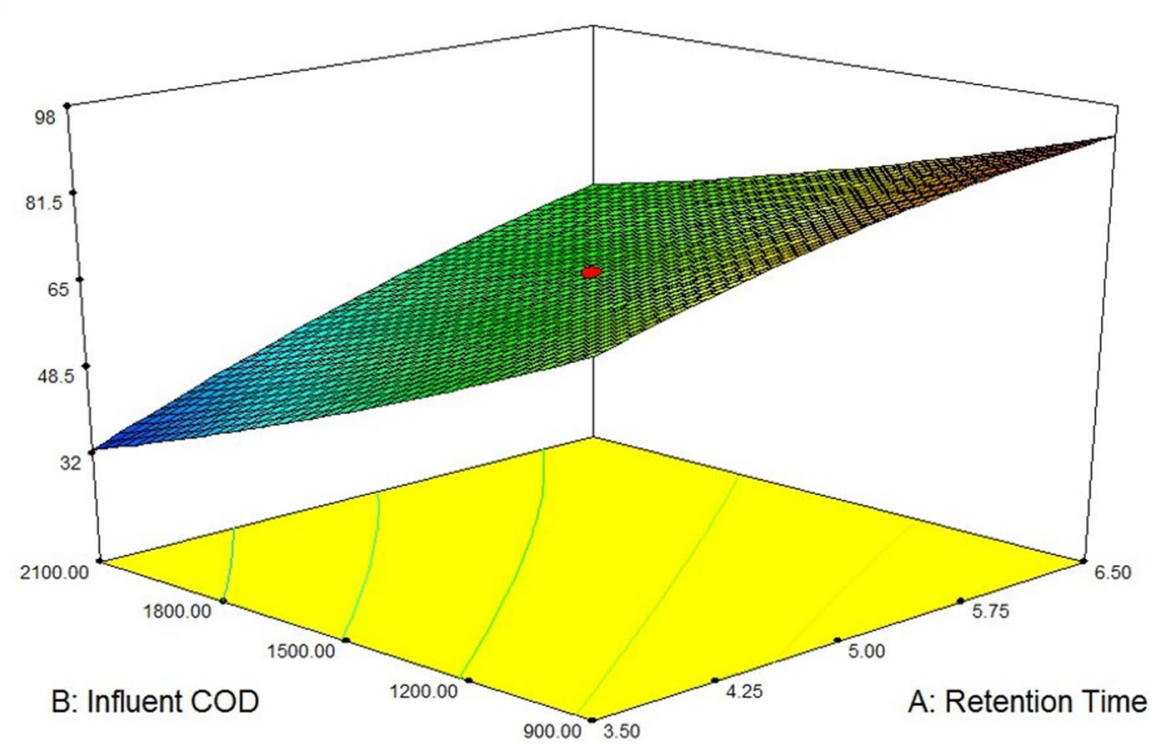

Fig. 7 The effect of retention time and influent COD concentration (flow recirculation percentage $=27.5 \%$ )

(for $900 \mathrm{mg} / \mathrm{L} \mathrm{COD}$ and $6.5 \mathrm{~h}$ retention time). The output COD in $89.75 \%$ removal efficiency was $99 \mathrm{mg} / \mathrm{L}$, which complies with environmental regulations such as USEPA and CEPA standards.

A closer look at Fig. 7 indicates the more significant effect of retention time in comparison with influent COD concentration. This would indicate the importance of finding an optimum level between these two variables.

\subsubsection{The effect of retention time and flow recirculation percentage}

Figure 8 shows the effect of retention time and flow recirculation percentage on removal efficiency. The retention time ranged from 3.5 to $6.5 \mathrm{~h}$, and flow recirculation percentage ranged from 20 to $35 \%$. These changes caused decline in the COD removal efficiency in the range of $35 \%$ ( $975 \mathrm{mg} / \mathrm{L}$ output COD) to $84 \%$ 


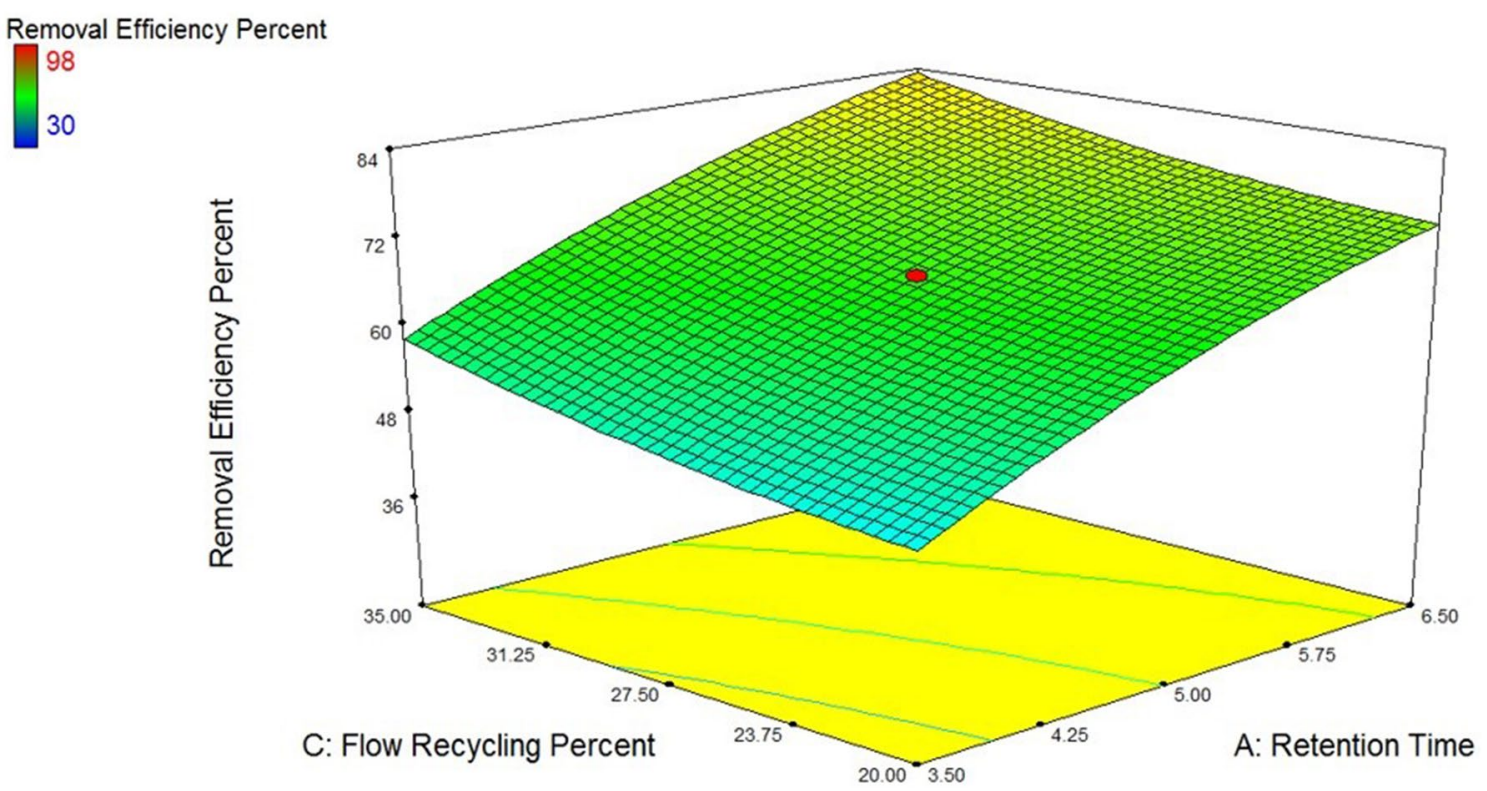

Fig. 8 The effect of retention time and flow recirculation percentage (influent COD $=1500 \mathrm{mg} / \mathrm{L}$ )

(240 mg/L output COD). As shown in Fig. 8, FBSSBR, COD removal efficiency in the system increased by the increase of these two factors. By using the FBSSBR system idea, some non-degraded pollutants entered reactor one again. Therefore, microorganisms had more chances to adapt and remove the COD. Increasing the retention time also gave more exposure time to microorganisms and improved COD removal efficiency.

\subsubsection{The effect of influent COD concentration and flow recirculation percentage}

Figure 9 shows the effect of changing in influent COD concentration and flow recirculation percentage. The influent COD concentration range was $900-2100 \mathrm{mg} / \mathrm{L}$, and flow recirculation percentage range was $20-35 \%$. In these conditions, the removal efficiency changed from $48 \%$ (1092 mg/L output COD) to $84 \%$ ( $72 \mathrm{mg} / \mathrm{L}$ output COD). It seems reduction in influent $C O D$ concentration positively

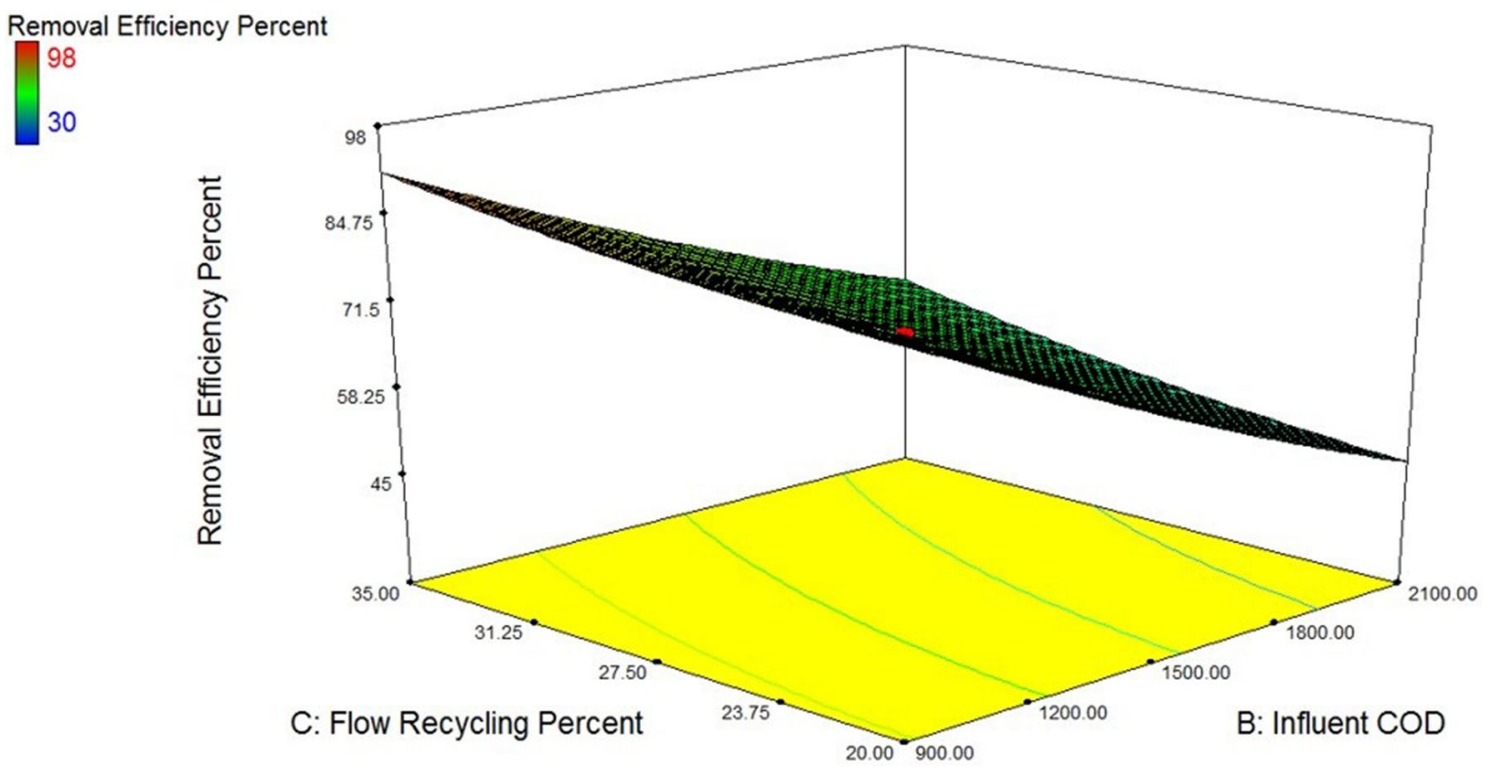

Fig. 9 The effect of influent COD concentration and flow recirculation percentage (retention time $=5 \mathrm{~h}$ ) 
Fig. 10 The effect of three independent variables
Removal Efficiency Percent

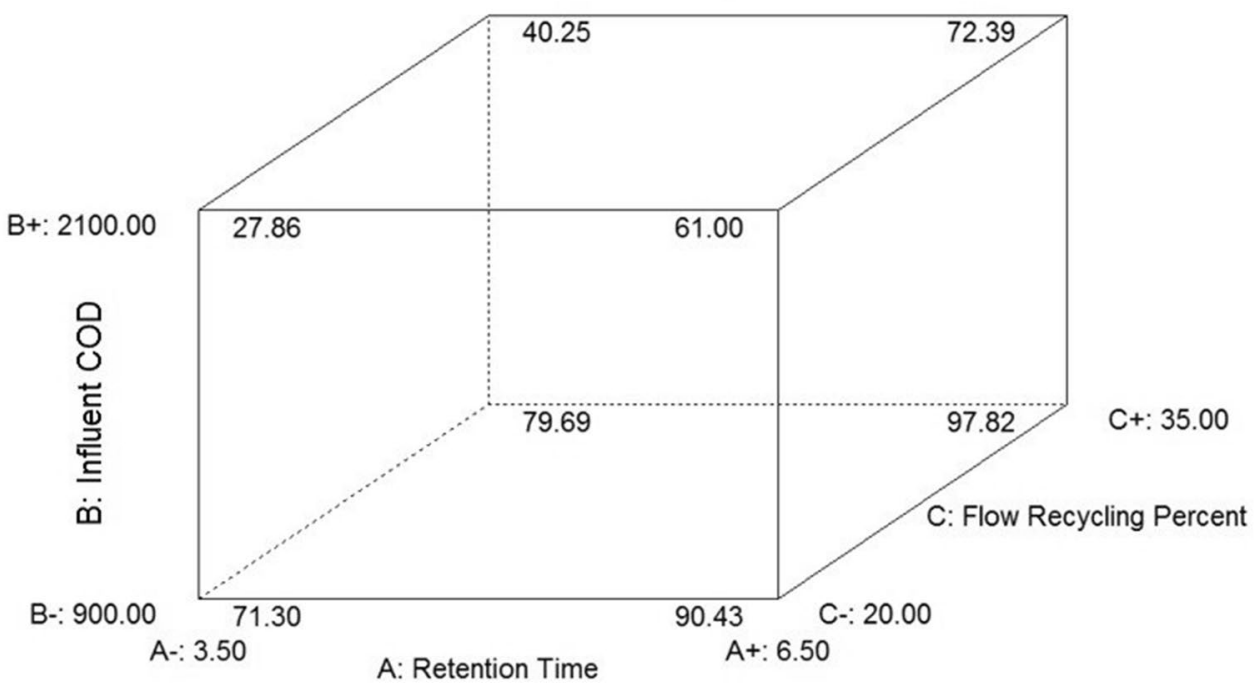

the $3.5 \mathrm{~h}$ of retention time, $2100 \mathrm{mg} / \mathrm{L}$ of influent COD concentration, and $20 \%$ of flow recirculation percentage. Output COD in maximum removal was $72 \mathrm{mg} / \mathrm{L}$.

\subsection{Interaction effects of parameters}

Interaction diagrams show the interactive effect of two variables on removal efficiency. These effects can be synergetic (where two variables make a positive effect on each other for removal efficiency) or antagonistic (where two variables tend to weaken positive effects of each other on the removal efficiency).
Fig. 11 Interactive effect of retention time and flow recirculation percentage (influent $\mathrm{COD}=1500 \mathrm{mg} / \mathrm{L}$ )

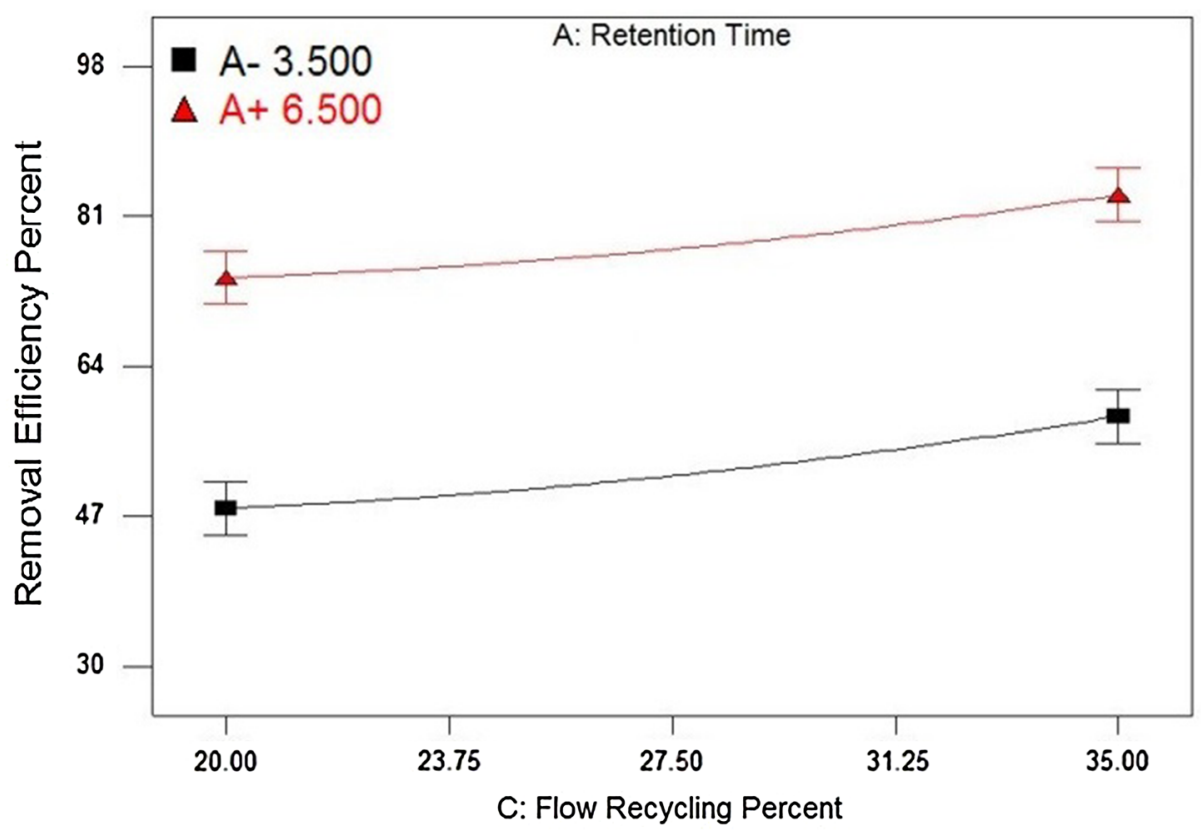

SN Applied Sciences 
Fig. 12 Interactive effect of retention time and influent COD concentration (flow recirculation percentage $=27.5 \%$ )

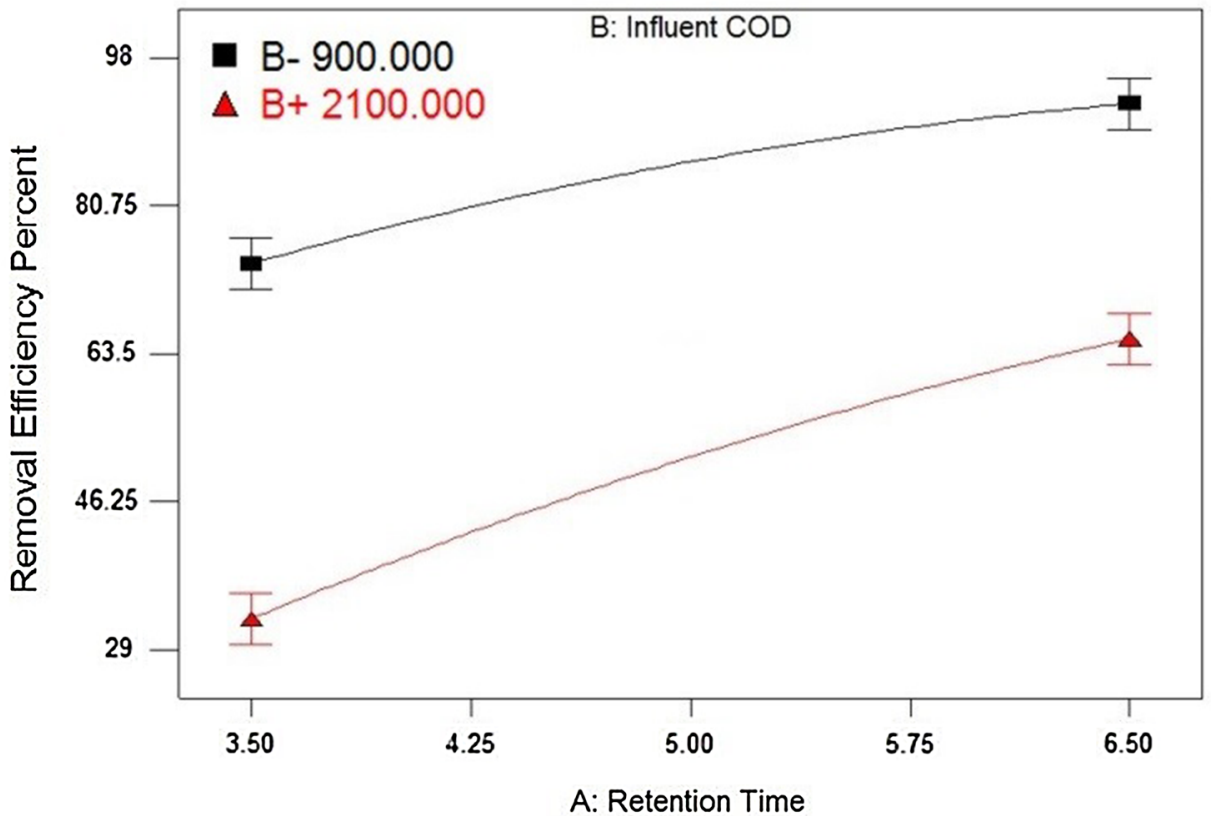

\subsubsection{Interactive effect of retention time and flow recirculation percentage}

Figure 11 shows the interaction between retention time and flow recirculation percentage. In this figure, when retention time is $3.5 \mathrm{~h}$, by changing inflow recirculation percentage from 20 to $35 \%$, change in removal efficiency is $47-60 \%$. With $6.5 \mathrm{~h}$ retention time and the same situation, there was a shift from 73 to $84 \%$ in removal efficiency. The diagram slope in $3.5 \mathrm{~h}$ of retention time is 0.87 , and $6.5 \mathrm{~h}$ of retention time is 0.73 . This minimal difference indicates the little effect of these two factors on each other.

\subsubsection{Interactive effect of retention time and influent COD concentration}

Figure 12 depicts the interactive effect of influent COD concentration and retention time. In this figure, by applying changes in retention time between 3.5 and $6.5 \mathrm{~h}$, removal efficiency changed from 75 to $92 \%$ when the influent COD was $900 \mathrm{mg} / \mathrm{L}$. Moreover, the change in removal efficiency was $33-65 \%$ when influent COD was $2100 \mathrm{mg} / \mathrm{L}$. The diagram slope of $900 \mathrm{mg} / \mathrm{L}$ of influent COD concentration is 5.67 , and in $2100 \mathrm{mg} / \mathrm{L}$ of influent COD concentration is 10.67. This difference indicates the antagonistic effect of these two factors on each other. Despite less removal efficiency in higher influent CODs, raise in retention time has stronger effect on samples with higher initial COD.

\subsubsection{Interactive effect of influent COD concentration and flow recirculation percentage}

Figure 13 shows the interactive effect of flow recirculation percentage and influent COD concentration. In this figure, where the flow recirculation is $20 \%$, by changing influent COD concentration (between 900 and $2100 \mathrm{mg} / \mathrm{L} \mathrm{COD}$ ), removal efficiency changed from 84.5 to $47 \%$, and when there was $35 \%$ flow recirculation percentage, removal efficiency deduced from 90.2 to $59 \%$.

\subsection{Mathematical model}

After results analysis, Eq. 1 was obtained.

Removal Efficiency percent $=+86.52052+14.73595 \times$ Retention Time -0.068207 Influent COD

$$
\begin{aligned}
& -1.02736 \text { flow recirculation percentage }+3.88889 \mathrm{E}-003 \times \text { Retention Time } \\
& \times \text { Influent COD }-0.022222 \text { Retention Time } \times \text { flow recirculation percentage } \\
& +2.22222 \mathrm{E}-004 \text { Influent COD } \times \text { flow recirculation percentage } \\
& -1.14133 \times \text { Retention Time }{ }^{2}+4.65181 \mathrm{E}-006 \times \text { Influent } \mathrm{COD}^{2} \\
& +0.026629 \times \text { flow recirculation percentage }
\end{aligned}
$$


Fig. 13 Interactive effect of influent COD concentration and flow recirculation percentage (retention time $=5 \mathrm{~h}$ )

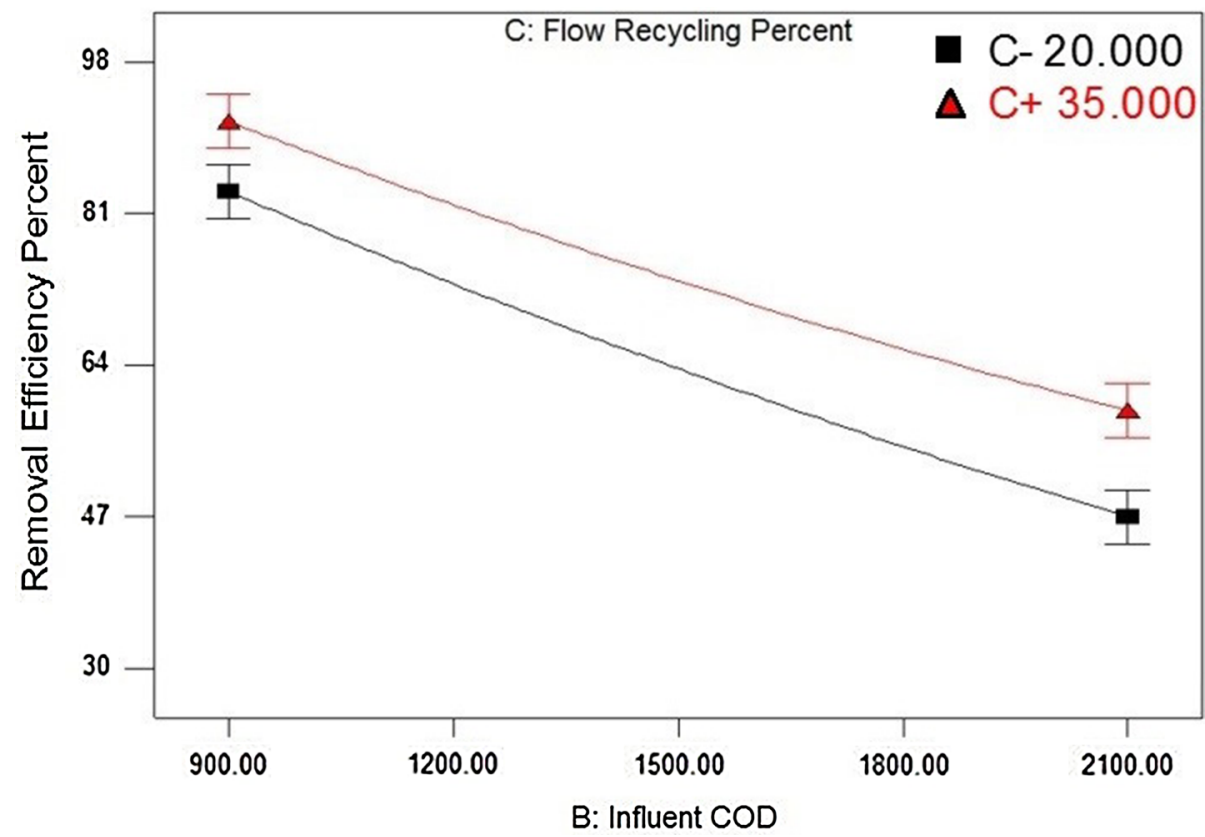

Based on Eq. 1, the effect of retention time is more than the other two factors. The comparison between effectiveness of each factor is as the following:

Retention Time $>$ flow recirculation percentage $>$ Influent COD

\subsection{Analysis of variance}

The ANOVA test strategy is based on using data to calculate the effect of each factor on the results. Table 6 indicates the ANOVA analysis result. The mean square and Fisher value are some of the factors of this table, but the important column in this table is the $P$ value column.
The $P$ value of the model was below 0.0001 , which shows that the presented mathematical model is statistically significant.

\subsection{Optimum condition and validation investigation}

The optimum condition occurred in the 3.52-h of retention time, $1667.76 \mathrm{mg} / \mathrm{L}$ of influent COD concentration, and $23.23 \%$ of flow recirculation percentage. Due to this condition, based on the mathematical equation, the optimum removal efficiency was $47 \%$. Based on experimental
Table 6 Analysis of variance results

\begin{tabular}{llrrrr}
\hline Source & Sum of squares & df & Mean squares & F value & $\begin{array}{r}P \text { value } \\
\text { prob }>F\end{array}$ \\
\hline Model & 6918.37 & 9 & 768.71 & 76.54 & $<0.0001$ \\
A-retention time & 224,360 & 1 & 2243.60 & 223.40 & $<0.0001$ \\
B-influent COD & 4048.41 & 1 & 4048.41 & 403.11 & $<0.0001$ \\
C-flow recirculation & 334.07 & 1 & 334.07 & 33.26 & 0.0002 \\
$\quad$ percentage & & & & & \\
AB & 98.00 & 1 & 98.00 & 9.76 & 0.0108 \\
AC & 0.50 & 1 & 0.50 & 0.050 & 0.8279 \\
BC & 8.00 & 1 & 8.00 & 0.80 & 0.3931 \\
A $^{2}$ & 95.04 & 1 & 95.04 & 9.46 & 0.0117 \\
B $^{2}$ & 40.42 & 1 & 40.42 & 4.02 & 0.0726 \\
C $^{2}$ & 32.33 & 1 & 32.33 & 3.22 & 0.1030 \\
Residual & 100.43 & 10 & 10.04 & & \\
Lack of fit & 100.43 & 5 & 20.09 & & \\
Pure error & 0.000 & 5 & 0.000 & & \\
Cor total & 7018.80 & 19 & & &
\end{tabular}


Fig. 14 Predicted values versus actual values

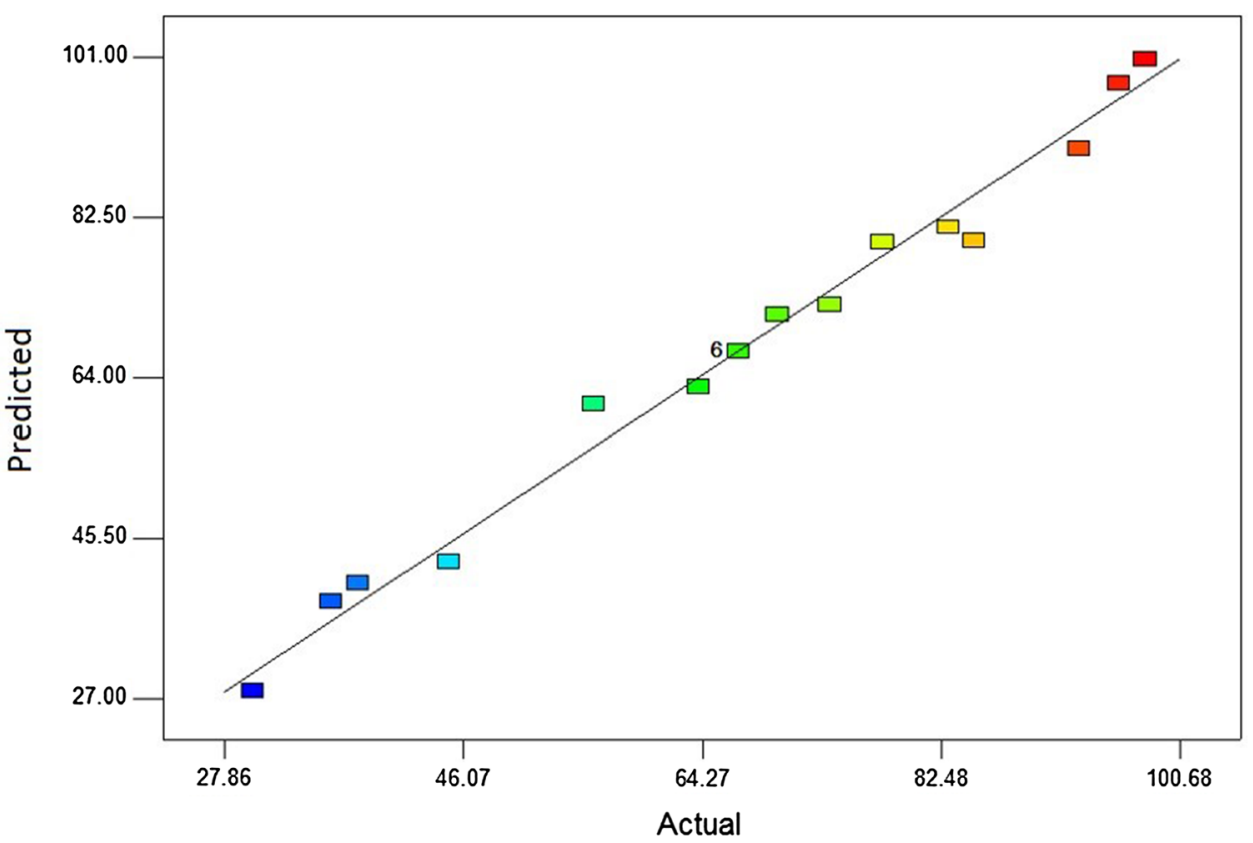

results, this removal efficiency had less than $5 \%$ error, and this error showed the model's accuracy. The experimental results confirmed the model results ultimately, as seen in Fig. 14.

\section{Conclusions}

This research studied FBSSBR's practical factors simultaneously. The RSM model was successfully applied to investigate the effect of three independent factors. The retention time was the most effective factor. Influent COD concentration by changing the environment's toxicity was the next effective factor. Approximately $97.82 \%$ was the highest removal efficiency. Among the other biological reactors, FBSSBR was successful in PG treatment.

\section{Compliance with ethical standards}

Conflict of interest The authors declare they have no conflict of interest.

\section{References}

1. Azizpour F, Qaderi F (2019) Optimization modeling and uncertainty investigation of phenolic wastewater treatment by photocatalytic process in cascade reactor. Environ Dev Sustain. https ://doi.org/10.1007/s10668-019-00480-8

2. Abdel-Fatah MA, Shaarawy HH, Hawash SI (2019) Integrated treatment of municipal wastewater using advanced electro-membrane filtration system. SN Appl Sci. https://doi. org/10.1007/s42452-019-1178-9

3. Alamdar R, Kumar V, Moghtaderi T, Naghibi SJ (2019) Groundwater quality evaluation of Shiraz City, Iran using multivariate and geostatistical techniques. SN Appl Sci 1:1367. https://doi. org/10.1007/s42452-019-1108-x

4. Albuquerque MTD, Antunes IMHR, Oliveira NP, Pelletier G (2019) Impact of sewage effluent discharges prediction using QUAL2Kw in a sensitive protected area: Portugal. SN Appl Sci. https://doi.org/10.1007/s42452-019-1095-y

5. Amritha A, Sundararajan M, Rejith RG, Mohammed-Aslam MA (2019) La-Ce doped $\mathrm{TiO}_{2}$ nanocrystals: a review on synthesis, characterization and photocatalytic activity. SN Appl Sci 1:1441. https://doi.org/10.1007/s42452-019-1455-7

6. Asadi P, Amini Rad H, Qaderi F (2019) Comparison of Chlorella vulgaris and Chlorella sorokiniana pa.91 in post treatment of dairy wastewater treatment plant effluents. Environ Sci Pollut Res. https://doi.org/10.1007/s11356-019-06051-8

7. Babanezhad E, Amini Rad H, Hosseini Karimi SS, Qaderi F (2017) Investigating nitrogen removal using simultaneous nitrification-denitrification in transferring wastewater through collection networks with small-diameter pipes. Water Pract Technol 12:396-405. https://doi.org/10.2166/wpt.2017.044

8. Babanezhad E, Qaderi F, Salehi Ziri M (2018) Spatial modeling of groundwater quality based on using Schoeller diagram in GIS base: a case study of Khorramabad, Iran. Environ Earth Sci 77:339. https://doi.org/10.1007/s12665-018-7541-0

9. Bezerra MA, Santelli RE, Oliveira EP, Villar LS, Escaleira LA (2008) Response surface methodology (RSM) as a tool for optimization in analytical chemistry. Talanta 76:965-977

10. Cardoso CMM, Zavarize DG, Lago PA, Pedroza MM, Brum SS, Mendonça ARV (2019) Evaluating adsorbent properties of drinking water treatment plant sludge-based carbons activated by $\mathrm{K}_{2} \mathrm{CO}_{3} / \mathrm{CH}_{3} \mathrm{COOH}$ : a low-cost material for metal ion remediation. SN Appl Sci 1:686. https://doi.org/10.1007/s4245 2-019-0709-8

11. Chiavola A, Farabegoli G, Antonetti F (2014) Biological treatment of olive mill wastewater in a sequencing batch reactor. Biochem Eng J 85:71-78 
12. Faghih Nasiri E, YousefiKebria D, Qaderi F (2018) An experimental study on the simultaneous phenol and chromium removal from water using titanium dioxide photocatalyst. Civil Eng $J$ 4(3):585-593. https://doi.org/10.28991/cej-0309117

13. Faghih Nasiri E, Yousefi Kebria D, Qaderi F (2019) The degradation of phenol in water solution by immobilized $\mathrm{TiO}_{2}$ photocatalysis. J Civil Environ Eng 48(93):43-49

14. Fakhru'razi A, Pendashte A, Abdullah $C L$, AwangBiak DR, Madaeni SS, Abidin ZZ (2009) Review of technologies for oil and gas produced water treatment. J Hazard Mater 170:530-551

15. Farzadkia M, Rezaei Kalantary R, Mousavi G, Jorfi S, Gholami $M$ (2010) The effect of organic loading on propylene glycol removal using fixed bed activated sludge hybrid reactor. Chem Biochem Eng Q 24(2):227-234

16. Greenberg AE, Clesceri LS, Eaton AD (2000) Standard methods for the examination of water and wastewater, 20th edn. American Public Health, Washington

17. Khalegh R, Qaderi F (2019) Optimization of the effect of nanoparticle morphologies on the cost of dye wastewater treatment via ultrasonic/photocatalytic hybrid process. Appl Nanosci. https://doi.org/10.1007/s13204-019-00984-9

18. Krithika D, Philip L (2015) Treatment of wastewater from waterbased paint industries using submerged attached growth reactor. Int Biodeterior Biodegrad 107:31-41

19. Pajoum Shariati F, Qaderi F, Haeri H (2019) Using moving bed biofilm reactor including kaldness media in treatment of wastewater containing light component petroleum. J Civil Environ Eng 49:1-19

20. Qaderi F, Ayati B, Ganjidoust H (2011) Role of moving bed biofilm reactor and sequencing batch reactor in biological degradation of formaldehyde wastewater. Iran J Environ Health Sci Eng 8(4):295-306

21. Qaderi F, Babanezhad E (2017) Prediction of the groundwater remediation costs for drinking use based on quality of water resource, using artificial neural network. J Clean Prod 161:840849. https://doi.org/10.1016/j.jclepro.2017.05.187

22. Qaderi F, Sayahzadeh AH, Azizi M (2018) Efficiency optimization of petroleum wastewater treatment by using of serial moving bed biofilm reactors. J Clean Prod 192:665-677. https://doi. org/10.1016/j.jclepro.2018.04.257

23. Qaderi F, Sayahzadeh AH, Azizpour F, Vosughi P (2018) Efficiency modeling of serial stabilization ponds in treatment of phenolic wastewater by response surface methodology. Int J Environ Sci Technol. https://doi.org/10.1007/s13762-018-1816-6

24. Qaderi F, Asadi P, Tamadoni A, Azizi M (2018) Evaluation of sustainability of development in zone 22 of Tehran by ecological footprint method. Geogr Dev Iran J 16(50):231-245. https://doi. org/10.22111/gdij.2018.3575

25. Qaderi F, Ayati B, Ganjidoust H, Sarraf-Mamoory R (2015) Investigation of kinetic and intermediate products of acid orange 7 removal by hybrid ozonation/photocatalytic processes. Modares J Civil Eng 15(2):79-89

26. Qaderi F, Sayahzadeh AH, Ebrahimi GM (2019) Optimization of effective environmental parameters on Astrazon Red GTL removal by dominant species Bacillus and Aeromonas: in a concurrent culture study. J Mol Cell Res 32(1):1-15

27. Qaderi F, Ayati B (2014) Comparison of MBBR and SBAR in treating toxic formaldehyde wastewater. J Civil Environ Eng 44(74):99-106

28. Qaderi F, Ayati B, Ganjidoust H (2012) Comparing the efficiency of MBBR and SBR in treating wastewater containing formaldehyde. Amirkabir J Civil Eng 43(2):43-50

29. Qaderi F, Ayati B, Ganjidoost H, Sarraf MR (2015) Treatment of wastewater containing acid orange 7 using ozonation process and determination of the intermediate by-products. J Water Wastewater 26(2):13-23
30. Robinson T, McMullan G, Marchant R, Nigam P (2001) Remediation of dyes in textile effluent: a critical review on current treatment technologies with a proposed alternative. Biores Technol 77:247-255

31. Sezgin N, Tonuk GU (2013) Anaerobic treatability of wastewater contaminated with propylene glycol. Bull Environ Contam Toxicol 91(3):320-323

32. Shariati SRP, Bonakdarpour B, Zare N, Ashtiani FZ (2011) The effect of hydraulic retention time on the performance and fouling characteristics of membrane sequencing batch reactors used for the treatment of synthetic petroleum refinery wastewater. Biores Technol 102:7692-7699

33. Sheikholeslami M (2017) Magnetic field influence on $\mathrm{CuO}-\mathrm{H}_{2} \mathrm{O}$ nano fluid convective flow in a permeable cavity considering various shapes for nanoparticles. Int J Hydrogen Energy 42:19611-19621

34. Sheikholeslami M (2018) Solidification of NEPCM under the effect of magnetic field in a porous thermal energy storage enclosure using CuO nanoparticles. J Mol Liq 263:303-315

35. Sheikholeslami $M(2018)$ Numerical modeling of nano enhanced PCM solidification in an enclosure with metallic fin. J Mol Liq 259:424-438

36. Sheikholeslami M (2018) Numerical simulation for solidification in a LHTESS by means of nano-enhanced PCM. J Taiwan Inst Chem Eng 86:25-41

37. Sheikholeslami $\mathrm{M}(2018)$ Influence of magnetic field on $\mathrm{Al}_{2} \mathrm{O}_{3}$ $\mathrm{H}_{2} \mathrm{O}$ nanofluid forced convection heat transfer in a porous lid driven cavity with hot sphere obstacle by means of LBM. J Mol Liq 263:472-488

38. Sheikholeslami M (2018) Finite element method for PCM solidification in existence of CuO nanoparticles. J Mol Liq 265:347-355

39. Sheikholeslami M, Rokni HB (2018) Magnetic nanofluid flow and convective heat transfer in a porous cavity considering Brownian motion effects. Phys Fluids 30(1):1-8. https://doi. org/10.1063/1.5012517

40. Sheikholeslami M, Ghasemi A (2018) Solidification heat transfer of nanofluid in existence of thermal radiation by means of FEM. Int J Heat Mass Transf 123:418-431

41. Sheikholeslami Z, YousefiKebria D, Qaderi F (2018) Nanoparticle for degradation of BTEX in produced water; an experimental procedure. J Mol Liq 246:476-482. https://doi.org/10.1016/j. molliq.2018.05.096

42. Sheikholeslami Z, YousefiKebria D, Qaderi F (2018) Investigation of photocatalytic degradation of BTEX in produced waterusing $\mathrm{Y}-\mathrm{Fe}_{2} \mathrm{O}_{3}$ nanoparticle. J Therm Anal Calorim. https://doi. org/10.1007/s10973-018-7381-x

43. Sheikholeslami M, Mahian O (2019) Enhancement of PCM solidification using inorganic nanoparticles and an external magnetic field with application in energy storage systems. J Clean Prod 215:963-977

44. Sheikholeslami M (2019) New computational approach for exergy and entropy analysis of nanofluid under the impact of Lorentz force through a porous media. Comput Methods Appl Mech Eng 344:319-333

45. Sheikholeslami $\mathrm{M}$ (2019) Numerical approach for $\mathrm{MHD} \mathrm{Al}_{2} \mathrm{O}_{3}-$ water nano fluid transportation inside a permeable medium using innovative computer method. Comput Methods Appl Mech Eng 344:306-318

46. Singh M, Srivastava RK (2011) Sequencing batch reactor technology for biological wastewater treatment: a review. Asia Pac J Chem Eng 6:3-13

47. Taghizadeh M, Kebria DY, Qaderi F (2019) Benzene and toluene removal from saline water with coupled membrane process and nanophotocatalyst. J Pet Res 27(10300695):168-179

48. Talaiekhozani A, Jorfi S, Fulazzaky MA, Ponraj M, Abd Majid MZ, Navarchian AH, Talaie MR, Zare S (2014) Lab-scale 
optimization of propylene glycol removal from synthetic wastewater using activated sludge reactor. Desalin Water Treat 52(19-21):3585-3593

49. Tamadoni A, Qaderi F (2019) Optimization of soil remediation by ozonation for PAHs contaminated soils. Ozone Sci Eng. https ://doi.org/10.1080/01919512.2019.1615865

50. Tavakoli Moghadam M, Qaderi F (2019) Modeling of petroleum wastewater treatment by $\mathrm{Fe} / \mathrm{Zn}$ nanoparticles using the response surface methodology and enhancing the efficiency by scavenger. Results Phys 15:102566-102576. https://doi. org/10.1016/j.rinp.2019.102566

51. Wang HY, Hu YN, Cao GP, Yuan WK (2011) Degradation of propylene glycol wastewater by Fenton's reagent in a semi-continuous reactor. Chem Eng J 170:75-81

52. Weidhaas J, Lin LL, Buzby K (2016) A case study for orphaned chemicals: 4-methylcyclohexane methanol (MCHM) and propylene glycol phenyl ether (PPH) in riverine sediment and water treatment processes. Sci Total Environ 574:1396-1404
53. Weste R, Banton M, Hu J, Klapacz J (2014) The distribution, fate, and effects of propylene glycol substances in the environment. Rev Environ Contam Toxicol 232:107-138

54. Yavari SM, Qaderi F (2018) Determination of thermal pollution of water resources caused by Neka power plant through processing satellite imagery. Environ Dev Sustain. https://doi. org/10.1007/s10668-018-0272-2

55. Zar T, Graeber C, Perazella MA (2007) Recognition, treatment, and prevention of propylene glycol toxicity. Semin Dial 20(3):179-284

Publisher's Note Springer Nature remains neutral with regard to jurisdictional claims in published maps and institutional affiliations. 